\title{
Pasture plant breeding in New Zealand: where to from here?
}

\author{
H.S.EASTON ${ }^{1}$, J.M.AMYES ${ }^{2}$, N.E.CAMERON ${ }^{3}$, R.B.GREEN ${ }^{4}$, G.A.KERR ${ }^{5}$, \\ M.G.NORRISS ${ }^{2}$ and A.V.STEWART ${ }^{6}$ \\ ${ }^{1}$ AgResearch Grasslands, Private Bag 11008, Palmerston North \\ ${ }^{2}$ Wrightson Research, P.O. Box 939, Christchurch \\ ${ }^{3}$ Cropmark Seeds Ltd, P.O. Box 16574, Christchurch \\ ${ }^{4}$ Agricom NZ Ltd, P O Box 539, Ashburton \\ ${ }^{5}$ Agriseeds, 2547 Old West Coast Rd, RD 1, Christchurch \\ ${ }^{6}$ Pyne Gould Guinness, P.O. Box 3100, Christchurch \\ sydney.easton@agresearch.co.nz
}

\begin{abstract}
Ecologically sustainable pastures remain the base of New Zealand's competitive advantage in livestock production, but while modest but steady productivity gains from pasture plant breeding have been documented, these appear to be difficult to convert to livestock production, and pasture production is perceived as up against a ceiling. This paper discusses the contribution of pasture plant breeding, focusing on the ryegrasses, and to a lesser extent on white clover.

Heritable variation is evident in the basic components of herbage growth and herbage quality. However, changes to individual traits are not reflected in improved integrated field performance. More precise information is required on how factors interact. New breeding technologies will allow integrated improvement of interacting factors. Evaluation trials and modelling should be managed to provide feed-back identifying the specific requirements of future high-performing systems.
\end{abstract}

Keywords: New Zealand, plant breeding, ryegrass, white clover

\section{Introduction}

Pasture grazed in situ is the basis of New Zealand's ability to produce quality livestock product at competitive prices. Other feed sources are expensive and the profitability of using them to complement pasture is sensitive to small changes in prices of inputs and products (Penno et al. 1996). However, some farmers perceive that inability to grow more grass has become the key limiting factor in their operations.

Genetic improvement of pasture plants has been actively pursued in New Zealand for more than 75 years (Wratt $\&$ Smith 1983). Gains in productivity, disease resistance and forage quality have been regularly documented (Corkill 1949; Easton et al. 2001a; Easton et al. 1989; Easton et al. 1997; Kerr 1987; Woodfield 1999). However, gains have sometimes proved difficult to capture in animal production trials (Woodward et al. 2001) and their reality has been questioned (Bahmani et al. 2000; Thom et al. 1999). At the 2001 NZGA conference,
Clark, Matthew \& Crush (Clark et al. 2001) discussed limitations of New Zealand pastures as the feed supply to high performing livestock. They acknowledged the gains made but pointed out that they were not large, looked at some possibilities for further improvement and discussed the role of complementary foodstuffs.

\section{Documented genetic gains \\ Herbage yield}

Woodfield (1999) estimated rates of genetic gain for perennial ryegrass dry matter production to be between 0.25 and $0.73 \%$ per year, and for white clover between 1.21 and $1.49 \%$ per year.

Published data for Italian and perennial ryegrasses (Easton et al. 1997; Easton et al. 2001a) enable calculation of gains in dry matter production in the last 25-30 years (Figure 1a,b). For Italian ryegrasses, progress in total yield has been $1.5 \%$ per annum and for perennial ryegrasses $0.4 \%$ annually and $0.7 \%$ per annum for summer-autumn yield. This compares with a European estimate of $0.5 \%$ per year, most evident in 4yr-old swards (Wijk \& Reheul 1991). Spring yield for perennial ryegrass in New Zealand improved by only $0.1 \%$ per annum, illustrating that with the overall increase in yield there has been a shift of dry matter production into seasons where it is more limiting. In absolute terms, estimated cumulative increases in spring, summer and autumn yields from 1975 to 1995 were 65,500 and $300 \mathrm{~kg} / \mathrm{ha}$ DM respectively. Gains for winter production ( $0.4 \%$ per annum) have been more modest than for summer-autumn but better than for spring.

Yield differences may depend on the environment. For example, Chapman et al. (1987) showed greater productivity of Nui than Ruanui ryegrass on a warm hill slope only when nitrogen was applied.

\section{Disease resistance}

Disease resistance has been continually upgraded as the races of disease organisms evolve, particularly crown and stem rusts (Puccinia coronatus, P. graminis, Easton 
Figure 1a Annual yield of Italian ryegrass cultivars against year of synthetic constitution (estimated yields from multi-site comparison).

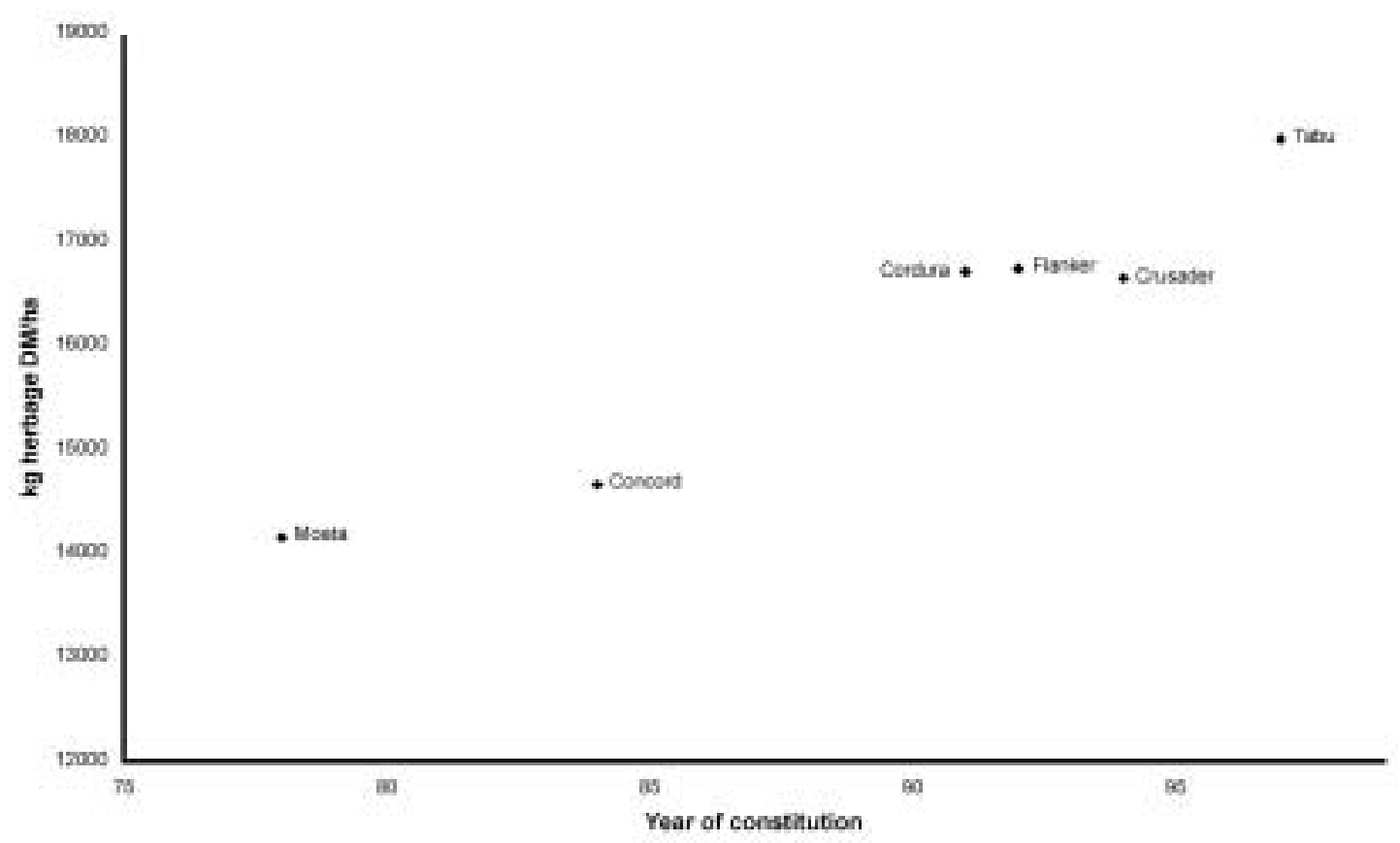

Figure $\mathbf{1 b}$ Summer-autumn yield of perennial ryegrass cultivars against year of synthetic constitution (estimated yields from multi-site comparison).

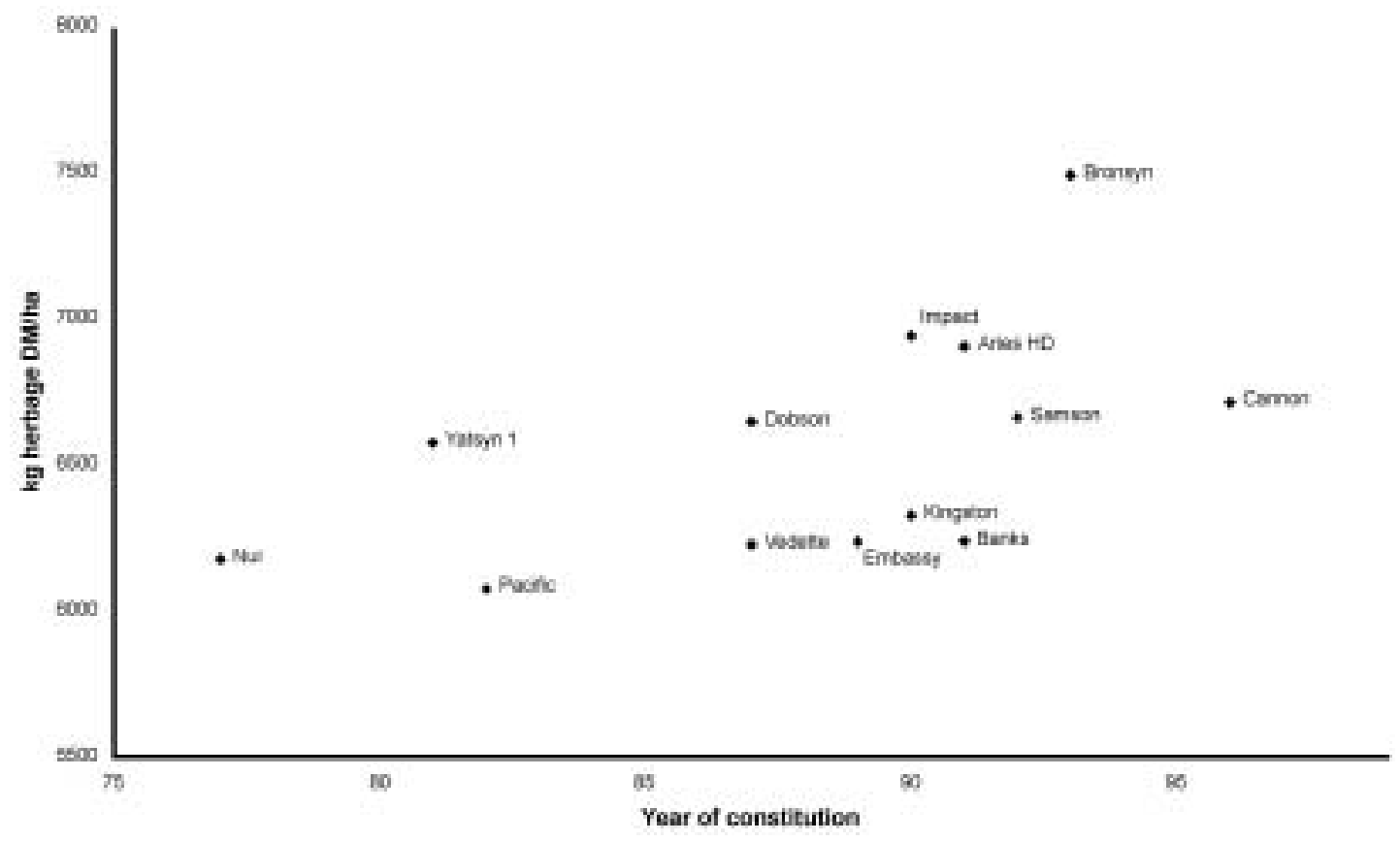


Figure 2 Rust resistance scores of perennial ryegrass cultivars against year of synthetic constitution (estimated from multi-site comparison).

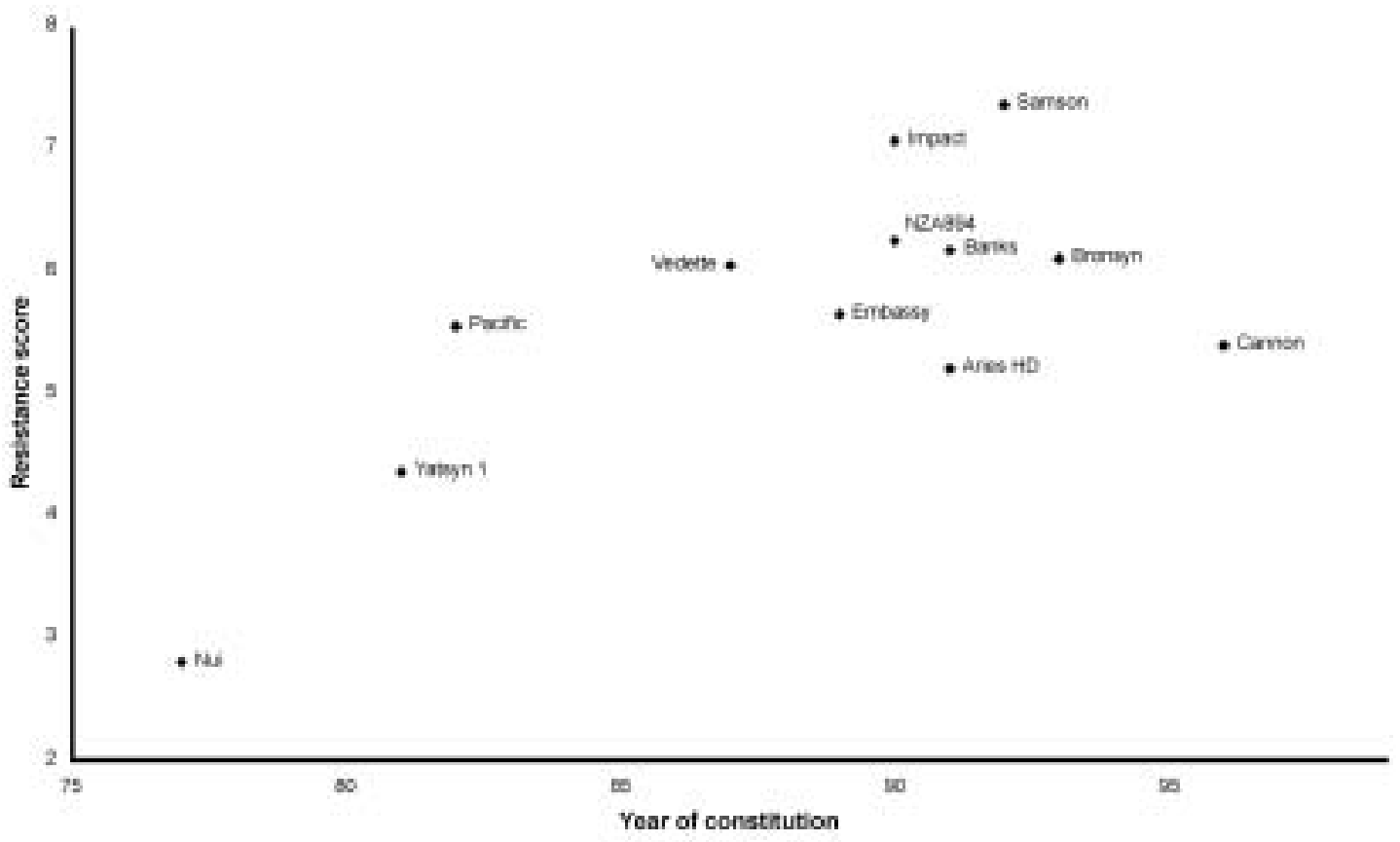

et al. 1989). Recent data for perennial ryegrass illustrate this (Figure 2), with cultivars developed since 1985 varying among themselves but all being better than the old standards.

Cocksfoot cultivars have also been improved for rust resistance (Rumball 1982) and white clover cultivars for leaf disease resistance and nematode tolerance (Cooper \& Chapman 1993).

\section{Forage quality}

In New Zealand, less attention has been paid to forage quality than in Europe, where ensiling is a major use of forage. However, work in the 1960's led to the development of 'Grasslands Marsden', by selecting for low leaf strength. The evaluation of Marsden (Lancashire \& Ulyatt 1975) was seriously confounded by the ryegrass endophyte, probably leading to an under-estimate of the gains made at the time. More recently, ryegrass has been selected for enhanced digestibility (Norriss, unpublished data).

Tetraploid annual and more recently perennial ryegrasses have been developed. Overseas research suggests grazing intakes 5\% greater than for diploids, leading to animal performance advantages of a similar order (Hageman et al. 1993).

For white clover, there has not been deliberate selection for content of soluble carbohydrate content, but cultivars varied from 13.4 to $20.5 \%$ of dry matter in spring at Palmerston North (Woodfield et al. 2001).

Anti-quality factors have also been addressed, for example the development of red clover with reduced levels of formononetin (Rumball et al. 1997). A nontoxic fungal endophyte strain has been identified and released, providing freedom from ryegrass staggers and related livestock impairment (Easton et al. 2001b).

\section{Heading date}

Almost all ryegrass found in old pastures in New Zealand is moderately early in heading date by international standards (e.g. Forde \& Suckling 1980), and until recently bred cultivars were from the same maturity group. In the last 15 years ryegrass cultivars with earlier (Embassy, Vedette, Meridian) and later (Impact, Quartet) heading dates have become available, offering respectively more feed in late winter or better quality feed in late spring.

\section{Prospects}

Can pasture plant breeding contribute to industry aims of substantial improvement in the volume and the consistency of production? Three areas are considered, the genetic potential for yield, the achievement of that potential and the quality of forage.

\section{Herbage yield potential}

A modelling exercise using the UDDER program 
involving different pasture species at four sites in different seasons found $83 \%$ of variation in herbage milk solids production to be associated with herbage yield (Barker et al. 1998). Impressive gains in yield of cereals have been achieved largely through shifts in allocation of resource (e.g. shorter straw, a shift from protein to carbohydrate in the storage tissues) or tolerance of close spacing. The harvested part of the pasture plant is the leaf, which is the site of photosynthesis and provides the energy required for development. The proteins and soluble carbohydrates of the leaf are metabolically active compounds involved in essential functions, so there are narrow limits to how much they can be changed. Only the root is not harvested, but reducing this in favour of the leaf would quickly compromise persistence. For these reasons, the aims in genetic improvement of pasture plants are more complex than those for arable crops.

As noted above, the genetic potential for herbage yield of perennial ryegrass has improved in the last 25 years, particularly in summer-autumn. There is no indication that this increase is slowing. Can we envisage more radical increases?

Herbage production involves fixing carbon through photosynthesis, transport and accumulation of photosynthetic products and the development of new tissue, all supported by uptake and transport of water and soil nutrients. Processes associated with photosynthesis, such as carbon assimilation, dark respiration and control of stomatal closure, were shown to vary and be heritable (Wilson 1975; Wilson 1982), but these differences did not translate into improved growth in the field. Changing the angle leaves present to the sun has been suggested as a means of enhancing light capture, and selection did secure changes (Parsons 1994), but again field results were disappointing. A limitation on photosynthesis is imposed by stomatal closure in response to water deficit, closing off the supply of $\mathrm{CO}_{2}$, and it may be possible to develop material able to fix carbon at lower levels of $\mathrm{CO}_{2}$ availability, indicated by the carbon isotope discrimination technique (Johnson 1993; Read et al. 1993). Statistically significant differences were recorded amongst families of New Zealand ryegrass for this trait in small exploratory experiments (Easton, unpublished data). Other possibilities canvassed by Clark et al. (2001) included shifting the carbohydrate : protein balance and delaying leaf senescence. More fundamental changes suggested were introducing enzymes associated with photosynthesis in tropical grasses and enzymes more tolerant of high temperatures.

Components of plant growth are thus under genetic control and can be altered by breeding, but these have not yet translated into major changes in field performance or into new cultivars. Incremental gains achieved by simple selection for yield have not perturbed the balance or feedback relations of the major interacting processes, but directly targeting individual components has been frustrated by such feedbacks. New techniques of study of gene action and interaction offer a means to understand how processes feed back and compensate. Application of these technologies to herbage yield, along with further selective pressure on the parameters of plant growth processes, may overcome the limitations encountered thus far.

\section{Consistent herbage yield}

Advances in the genetic potential of pasture plants are only of value if translated into on-farm performance. Pasture yields in well-fertilised trials do not appear to have greatly improved over those recorded some decades ago (Eerens et al. 2001; Hodgson 1989), despite improvements in genetic content of pastures, new fertiliser technology and advances in knowledge of plant physiology and ecology. There remain poorly understood restrictions on pasture yield, in apparently healthy pastures. In 17 NFVT trials of perennial ryegrass between 1990 and 2000, the mean yield of years 2 and 3 was $10 \%$ less than that of year 1, although these trials are fertilised to avoid any nutrient constraint. The greater grazing days contribution of new pastures on farms is usually ascribed to the release of mineralised nitrogen during cultivation. There is perhaps more than this. Temperature and moisture will always affect pasture growth, but more frequently achieving potential production would lift the mean "ceiling".

Areas of research likely to contribute to developing plants able to consistently achieve their yield potential are perennity and the maintenance of tiller populations, root development and longevity, and the significance and biology of diseases and pests usually regarded as minor. Heritable genetic variation in root growth (J.P.J. Eerens, pers. comm.) and the capacity of roots to penetrate resistant soil layers (J.R. Crush, pers. comm.) has been shown in recent studies. Pasture mealy bug has been associated with significant yield short-falls in some dryland conditions (Pennell et al. 2000), and application of systemic insecticide led to enhanced root proliferation in the apparent absence of root-feeding invertebrates (A.J. Popay, pers. comm.). Root traits have been difficult and expensive to measure. Modern materials and data capture systems offer new possibilities. Ready measurement of root morphology, determining the most desirable type of root and then selecting for it, probably using molecular markers, is likely to lead to more stressresistant plants.

Perennial ryegrass cultivars have been inoculated 
with the non-toxic endophyte strain AR1 (Easton et al. 2001b), that was isolated from an exotic ryegrass source. Some indications are that ryegrass infected with AR1 is less robust than the same cultivars naturally infected with wild-type endophyte (Popay \& Baltus 2001). Selection within ryegrass populations for adaptation to infection with AR1 is likely to lead to gains, bringing herbage yield of the non-toxic pastures consistently up to the highest levels (Easton et al. 2000).

\section{Forage quality}

Selection for forage quality has long been recognised as desirable and achievable (Corkill 1958). Progress has been impeded by lack of clarity on desirable traits, and by failure of the early results to translate to field advantages. Persistent attention to digestibility and content of soluble carbohydrates eventually resulted in Britain in improved cultivars (Humphreys 1989), and indications of enhanced animal performance (Miller et al. 2001). Heritable variation for the quality parameters protein and soluble carbohydrate content, digestibility, and fibre fractions is readily observable in ryegrass populations (for example Easton, unpublished). Whether enhanced soluble carbohydrate (and hence readily available energy) will improve livestock performance under New Zealand grazing conditions has still not been shown. No response was obtained from an infusion experiment simulating enhanced pasture (Cosgrove $e t$ al. 2001). However, development of experimental cultivars may now be the most cost-effective approach to a definitive response, and if livestock performance is not enhanced by simple increase in the available energy delivered by pasture, further research should determine why. Westwood \& Norriss (2000) reported significant gains in lamb production from new cultivars compared with previous germplasm, possibly due in part to differences in forage quality and/or intake. More radical enhancement of carbohydrate content by creating a sequestered non-metabolic storage source is a likely aim of genetic engineering.

Digestibility of fibre changes as cell walls mature. Lignin laid down with the cellulose is not only indigestible itself, but interferes with digestion of the cellulose (Stone 1994), depending on the nature of the chemical bonds within the ligni-cellulose complex. Identification and control of genes involved may counter the loss of digestibility as herbage matures.

Another limitation of livestock performance is forage intake. Digestibility is one factor affecting intake as is water content, but other factors are involved. Leaf shear strength may influence how quickly forage is harvested by the animal, and how quickly it breaks down in the rumen. Variation is heritable (Easton 1989), and some data from sheep grazing experimental lines showed promise (Inoue et al. 1989), but results were inconsistent (Inoue et al. 1994). Further work will lead to cultivars with more significantly reduced shear strength, and potentially more consistent effects on intake. However, while enhancing intake should lead to higher production per stock unit fed to appetite, it may not affect production when feed is rationed.

\section{Assessing impact and capturing gain}

Dry matter yield trials, supported by measurements for disease reaction, endophyte toxins and quality parameters where appropriate predict the contribution a cultivar will make to pasture and livestock performance. Applying the data to a verified model such as UDDER, as done by Barker et al. (1998) for a pasture species and management comparison, will enhance the accuracy of prediction within a nominated system, particularly where several traits are varying.

Livestock performance trials will verify performance and the predictive models. Such trials are complex and open to a range of interactions and confounding factors, but they are particularly important when a new concept is involved. Livestock performance trials have compared pasture species over a season in sheep (Fraser et al. 1999) and dairy (Thom et al. 1998) systems. Differences between cultivars in livestock performance have been shown using similar methodology (Chapman et al. 1987; Dodd et al. 2001; Ryan \& Widdup 1997; Westwood \& Norriss 2000; Westwood \& Norriss 2001). However other trials (for example cited by Dodd et al. 2001) have not done so. Livestock performance trials need to run for long enough to identify changing patterns with time (Dodd et al. 2001; Woodward et al. 2001), and be structured to identify underlying reasons if predicted differences are not realised. Clearly this is expensive, and resources should be focused on cultivars or groups of cultivars that embody new concepts.

Equally import, modelling and grazing trials need to identify adjustments required in farm systems if enhanced genetic potential is to be captured. Looking forward, application of models might identify potential cultivar improvements that would most enhance the profitability or sustainability of farm systems. Yield trials and livestock performance trials are widely used, as the above examples show. The use of modelling as an intermediate and interpreting step is an element which so far has been little used in cultivar evaluation.

\section{Conclusion}

Pasture plant breeding, exemplified in this paper by perennial ryegrass, has achieved significant incremental gains in herbage yield potential, in disease resistance and in range of maturity. There is no indication that incremental gain will not continue. 
Greater gains will be realised in future by directing attention to the basic components of plant growth processes, to the factors impairing consistent achievement of current potential and to factors of forage quality and herbage intake. Selection experiments focussed on single factors show heritable variation but changes in single factors often do not impact on field performance. Intensified research into the interactions between factors, and their genetic control, will extend the ability of pastures to feed high producing livestock.

\section{REFERENCES}

Bahmani, I.; Hazard, L.; Varlet-Grancher, C.; Betin, M.; Lemaire, G.; Matthew, C.; Thom, E.R. 2000. Differences in tillering of long- and short-leaved ryegrass genetic lines under full light and shade treatments. Crop Science 40: 1095-1102.

Barker, D.J.; Clark, D.A.; Thom, E.R.; Couchman, J.N.; Burton, R.N.; Dymock, N. 1998. Pasture species and drought impacts on milk yield 2. Predicted farm milk yield at four sites. Proceedings of the New Zealand Grassland Association 60: 45-50.

Chapman, D.F.; Lambert, M.G.; Anderson, C.B. 1987. Comparative performance of 'Grasslands Ruanui' and 'Grasslands Nui' perennial ryegrass cultivars in hill country. New Zealand Journal of Experimental Agriculture 15: 1-7.

Clark, D.A.; Matthew, C.; Crush, J.R. 2001. More feed for New Zealand dairy systems. Proceedings of the New Zealand Grassland Association 63: 283-288.

Cooper, B.M.; Chapman, D.F. 1993. Grasslands Prestige (G39), a white clover cultivar originating from northern New Zealand. pp. 458-459. In: Proceedings of the XVII International Grassland Congress.

Corkill, L. 1949. Pasture improvement in New Zealand. Empire Journal of Experimental Agriculture 17: 157169.

Corkill, L. 1958. Presidential address. Proceedings of the New Zealand Grassland Association 20: 1-10.

Cosgrove, G.P.; Parsons, A.J.; Marotti, D.M.; Rutter, S.M.; Chapman, D.F. 2001. Opportunities for enhancing the delivery of novel forage attributes. Proceedings of the New Zealand Society of Animal Production 61: 16-19.

Dodd, M.B.; Sheath, G.W.; Wedderburn, M.E.; Tarbotton, I.S. 2001. Long term performance of white clover cultivars oversown into summer-dry hill country. Proceedings of the New Zealand Grassland Association 63: 85-89.

Easton, H.S. 1989. Variability of leaf shear strength in perennial ryegrass. New Zealand Journal of Agricultural Research 32: 1-6.

Easton, H.S.; Baird, D.B.; Cameron, N.E.; Kerr, G.A.; Norriss, M.; Stewart, A.V. 2001a. Perennial ryegrass cultivars: herbage yield in multi-site plot trials.
Proceedings of the New Zealand Grassland Association 63: 183-188.

Easton, H.S.; Christensen, M.J.; Eerens, J.P.J.; Fletcher, L.R.; Hume, D.E.; Keogh, R.G.; Lane, G.A.; Latch, G.C.M.; Pennell, C.G.L.; Popay, A.J.; Rolston, M.P.; Sutherland, B.L.; Tapper, B.A. 2001b. Grass endophytes: a New Zealand grassland success story. Proceedings of the New Zealand Grassland Association 63: 37-46.

Easton, H.S.; Cooper, B.M.; Fraser, T.J.; Widdup, K.H. 1989. Crown rust on perennial ryegrass in field trials. Proceedings of the New Zealand Grassland Association 50: 253-254.

Easton, H.S.; Cooper, B.M.; Lyons, T.B.; Pennell, C.G.L.; Popay, A.J.; Tapper, B.A.; Simpson, W.R. 2000. Selected endophyte and plant variation. pp. 351356. In: Proceedings of the Grassland Conference 2000 - 4th International Neotyphodium/Grass Interactions Symposium. Eds. Paul, V. H.; Dapprich, P. D. Universität-Gesamthochschle Paderborn, Abteilung Soest, Fachbereich Agrarwirtschaft, Soest, Germany. Easton, S.; Baird, D.; Baxter, G.; Cameron, N.; Hainsworth, R.; Johnston, C.; Kerr, G.; Lyons, T.; McCabe, R.; Nichol, W.; Norriss, M.; Stewart, A.; Thom, E. 1997. Annual and hybrid ryegrass cultivars in New Zealand. Proceedings of the New Zealand Grassland Association 59: 239-243.

Eerens, J.P.J.; Crush, J.R.; Woodward, S.L.; MacDonald, K.A.; Carter, W.A. 2001. Milksolids production from different combinations of perennial ryegrass and white clover cultivars: I Trial design and pasture performance. Proceedings of the New Zealand Grassland Association 63: 91-96.

Forde, M.B.; Suckling, F.E.T. 1980. Genetic resources in high-rainfall hill pastures of New Zealand. 2. Description of the ryegrass collection. New Zealand Journal of Agricultural Research 23: 179-189.

Fraser, T.J.; Moss, R.A.; Daly, M.J.; Knight, T.L. 1999. The effect of pasture species on lamb performance in dryland systems. Proceedings of the New Zealand Grassland Association 61: 23-29.

Hageman, I.W.; Lantinga, E.A.; Schlepers, H.; Neuteboom, J.H. 1993. Herbage intake, digestibility characteristics and milk production of a diploid and two tetraploid cultivars of perennial ryegrass. pp. 459462. In: Proceedings of the XVII International Grassland Congress.

Hodgson, J. 1989. Increases in milk production per cow and per hectare: pasture production. Dairy Farming Annual 41: 76-82.

Humphreys, M.O. 1989. Water-soluble carbohydrates in perennial ryegrass breeding. II. Cultivar and hybrid progeny performance in cut plots. Grass and Forage Science 44: 237-244.

Inoue, T.; Brookes, I.M.; Barry, T.N.; John, A. 1989. 
Effects of selection for shear strength on the voluntary intake and digestion of perennial ryegrass fed to sheep. Proceedings of the New Zealand Society of Animal Production 49: 221-224.

Inoue, T.; Brookes, I.M.; John, A.; Kolver, E.S.; Barry, T.N. 1994. Effects of leaf shear breaking load on the feeding value of perennial ryegrass (Lolium perenne) for sheep. 2. Effects on feed intake, particle breakdown, rumen digesta outflow and animal performance. Journal of Agricultural Science 123: 137-147.

Johnson, R.C. 1993. Carbon isotype discrimination, water relations, and photosynthesis in tall fescue. Crop Science 33: 169-174.

Kerr, G.A. 1987. Evaluation of four perennial ryegrass cultivars in New Zealand. Proceedings of the New Zealand Grassland Association 48: 137-141.

Lancashire, J.A.; Ulyatt, M.J. 1975. Live-weight gains of sheep grazing ryegrass pastures with different cellulose contents. New Zealand Journal of Agricultural Research 18: 97-100.

Miller, L.A.; Moorby, J.M.; Davies, D.R.; Humphreys, M.O.; Scollan, N.D.; Macrae, J.C.; Theodorou, M.K. 2001. Increased concentration of water-soluble carbohydrate in perennial ryegrass (Lolium perenne L.). Milk production from late-lactation dairy cows. Grass and Forage Science 56: 383-394.

Parsons, A.J. 1994. Exploiting resource capture Grassland. pp. 315-349. In: Resource capture by crops. Eds. Monteith, J. L.; Scott, R. K.; Unsworth, M. H. Nottingham University Press, Loughborough, U.K.

Pennell, C.G.L.; Hume, D.E.; Ball, O.J.-P.; Easton, H.S.; Lyons, T.B. 2000. Effects of Neotyphodium lolii infection in ryegrass on root aphid and pasture mealy bug. In: Proceedings of the Grassland Conference 2000 - 4th International Neotyphodium/Grass Interactions Symposium" pp. 465-469 Eds. Paul, V. H.; Dapprich, P. D., Universität-Gesamthochschle Paderborn, Abteilung Soest, Fachbereich Agrarwirtschaft.

Penno, J.W.; Macdonald, K.A.; Bryant, A.M. 1996. The economics of No 2 dairy systems. Proceedings of the Ruakura Farmers' Conference 48: 11-19.

Popay, A.J.; Baltus, J.G. 2001. Black beetle damage to perennial grass infected with AR1 endophyte. Proceedings of the New Zealand Grassland Association 63: 267-271.

Read, J.J.; Asay, K.H.; Johnson, D.A. 1993. Divergent selection for carbon isotope discrimination in crested wheatgrass. Canadian Journal of Plant Science 73: 1027-1035.

Rumball, W. 1982. 'Grasslands Wana' cocksfoot (Dactylis glomerata L.). New Zealand Journal of Experimental Agriculture 10:51-52.

Rumball, W.; Keogh, R.G.; Miller, J.E.; Claydon, R.B. 1997. 'Grasslands G27' red clover (Trifolium pratense L.). New Zealand Journal of Agricultural Research
40: 369-372.

Ryan, D.L.; Widdup, K.H. 1997. Lamb and hogget growth on different white clover and ryegrass cultivar mixtures in southern New Zealand. Proceedings of the New Zealand Society of Animal Production 57: 182-185.

Stone, B.A. 1994. Prospects for improving the nutritive value of temperate, perennial pasture grasses. New Zealand Journal of Agricultural Research 37: 349363.

Thom, E.R.; Clark, D.A.; Van Vught, V.T.; Waugh, C.D. 1998. Pasture species and drought impacts on milk yield 1. Milk yield responses in the Waikato. Proceedings of the New Zealand Grassland Association 60: 39-44.

Thom, E.R.; Clark, D.A.; Waugh, C.D. 1999. Growth, persistence, and alkaloid levels of endophyte-infected and endophyte-free ryegrass pastures grazed by dairy cows in northern New Zealand. New Zealand Journal of Agricultural Research 42: 241-253.

Westwood, C.T.; Norriss, M.G. 2000. Performance by dairy cows grazing two perennial ryegrass cultivars. Proceedings of the New Zealand Society of Animal Production 60: 247-252.

Westwood, C.T.; Norriss, M.G. 1999. Liveweight changes in lambs grazing six perennial ryegrass cultivars. Proceedings of the New Zealand Grassland Association 61: 31-35.

Wijk, A.J.P.V.; Reheul, D. 1991. Achievements in fodder crops breeding in maritime Europe. pp. 13-18. In: Proceedings 16th meeting Fodder Crops Section, Eucarpia.

Wilson, D. 1975. Variation in leaf respiration in relation to growth and photosynthesis of Lolium. Annals of Applied Biology 80: 323-338.

Wilson, D. 1982. Response to selection for dark respiration rate of mature leaves in Lolium perenne and its effects on growth of young plants and simulated swards. Annals of Botany 49: 303-312.

Woodfield, D.R. 1999. Genetic improvements in New Zealand forage cultivars. Proceedings of the New Zealand Grassland Association 61: 3-7.

Woodfield, D.R.; Clifford, P.T.P.; Cousins, G.R.; Ford, J.L.; Baird, I.J.; Miller, J.E.; Woodward, S.L.; Caradus, J.R. 2001. Grasslands Kopu II and Crusader: new generation white clovers. Proceedings of the New Zealand Grassland Association 63: 103-108.

Woodward, S.L.; Macdonald, K.A.; Carter, W.A.; Eerens, J.P.J.; Crush, J.R. 2001. Milksolids production from different combinations of perennial ryegrass and white clover cultivars: II Milksolids production and farm profitability. Proceedings of the New Zealand Grassland Association 63: 97-102.

Wratt, G.S.; Smith, H.C. 1983. Plant Breeding in New Zealand. Butterworths, DSIR, Wellington. 309 pp. 